Черниш $A . \boldsymbol{C}$. аспірант кафедри української літератури Сумський державний педагогічний університет ім. А. С. Макаренка

\title{
ПСИХОТИП МИТЦЯ У РОМАНАХ-БІОГРАФІЯХ М. СЛАБОШПИЦЬКОГО
}

У статті означені складові характерів героїв біографічних романів М. Слабошпицького, принципи їхньої поведінки, моральні та духовні иінності, корпус почуттів, настроїв і роздумів персонажів, а також гострі душевні конфлікти й суперечності, їхні напружені психологічні проблеми, причини й наслідки психічних зривів.

Ключові слова: nсихотип, характер. 
В статье отмечены составляющие характеров героев биографических романов М. Слабошпицкого, принципь их поведения, моральные и духовные иенности, корпус чувств, настроений и размышлений персонажей, а также острые душевные конфликты и противоречия, их напряженные психологические проблемы, причины и следствия психических срывов.

Ключевые слова: психотип, характер.

In the articles heroes characters of M. Slaboshpytskyi biographic novels, principles of their behavior, moral and spiritual values, feelings, influenced reflections of personages, difficult heartfelt conflicts and contradictions, their tense psychological problems, causes and effects of psychical derangements are marked.

Key words: psychtype, characters.

В останні десятиліття особливої актуальності набув психоаналітичний підхід до вивчення творчості митців. У літературознавчому аналізі біографічних романів М. Слабошпицького "Марія Башкирцева (Життя за гороскопом)", "Поет із пекла (Тодось Осьмачка)", "Никифор Дровняк із Криниці”, "Що записано в книгу життя”, “Автопортрет художника в зрілості” важливе місце посідає осмислення психологічної концепції особистості. Аналізовані романи - багатогранні “психоделічні” (М. Слабошпицький) твори, у яких письменник-біограф окреслив широку гаму проблемнотематичних аспектів: у психологічному ключі осмислив духовну, культурну, ментальну, історичну, біографічну сфери життєтворчості Марії Башкирцевої, Тодося Осьмачки, Михайла Коцюбинського, Рафаеля Багаутдінова, Никифора Дровняка. Мета статті - проаналізувати внутрішню психологічну типологію митця й виявити засадничі риси характеротворення.

Завдання статті: 1) означити складові характерів героїв, принципи їхньої поведінки; 2) з'ясувати причини й наслідки психічних зривів і порушень у поведінці головних героїв.

У романі М. Слабошпицького “Марія Башкирцева (Життя за гороскопом)" героїня представлена як складна особистість: надзвичайно працьовита, надмірно амбіційна, самостійна, наполеглива, але емоційно неврівноважена, внаслідок чого у неї розвинулося хитання між впевненістю в своїх силах і повним розчаруванням. 
Переживання внутрішніх конфліктів призвело до порушень нервового розвитку Марії Башкирцевої. Надмірна працьовитість, абсолютне ігнорування світських заходів, постійні сумніви у своїх здібностях, хаотичні й тривожні думки в останній творчий період спричинили тимчасовий занепад духу, меланхолію, розпач: “Про що думати, чим утішити себе зараз, коли весь світ видається пустелею, коли iii розчавлює самотність безсонної ночі, коли жахає виразне розуміння невідворотності близького кінця?” [Слабошпицький 2008 б: 195]. Такі надривні стани героїні граничні з неврозом чи психічними зривами. Проте подібну реакцію Марії Башкирцевої на життєві реалії слушно розцінювати як один із способів можливої реалізації Я. Таким чином, поведінкова й емоційна модель образу головної героїні роману М. Слабошпицького "Марія Башкирцева (Життя за гороскопом)” визначається як особливий варіант самозахисту чи самовиправдання, скерований на вирішення внутрішнього конфлікту.

М. Слабошпицький змалював досить суперечливий образ Марії Башкирцевої. Його героїня - не власне ідея автора, не вигадка, а психологічно вмотивований тип творця-генія, який часто береться до роботи у хвилини внутрішньої дисгармонії, нервового напруження, психологічного стресу. Наслідком психологічних хитань, борінь, нестабільності, ймовірно, могли стати різноманітні страхи й психологічне відчуття самотності. Відсутність друзів, егоїстичність як складова характеротворення, дивакуватість - наслідкові грані самотності Марії Башкирцевої. Екзистенційну самоту героїня сублімувала у творчість, у той час як душевна самотність, не маючи змоги перевтілитися у продукт мистецької фантазії, перетворювалася у форми видимого психічного неспокою. Звідси героїня роману перебувала під згубним впливом страху перед невдачами, переживаючи невпевненість у власних силах, стимулюючи свою нервову систему на породження нервових розладів, підриваючи основи здорової психіки і здоров'я в цілому.

У романі-біографії “Поет із пекла (Тодось Осьмачка)", як і в романах "Марія Башкирцева (Життя за гороскопом)”, “Автопортрет художника в зрілості” та “Що записано в книгу життя” на- 
скрізною психологічною характеристикою героя також постає самотність. Настороженість і постійне відчуття психічного й екзистенційного страху вилилися у втрату надій на щире дружнє плече. Самотність, що на прикладі образу Тодося Осьмачки має різні форми свого прояву, є причиною складного характеру, рушієм життєвої лінії, наслідком страхітливого існування героя: «Його самотність має сотні варіантів: самотність людини перед лицем космосу, самотність України в байдужому до ї̈ долі світі, його особиста самотність за маргінесом суспільства у його многолюдdi» [Слабошпицький 2003: 146].

Назва твору "Поет із пекла" акцентує на проблемах душевного стану персонажа роману, з надр якого проріс талант Тодося Осьмачки-поета. Його внутрішній неспокій, дисгармонія, стихійність, некерованість були каталізаторами творчості поета. У ньому, на думку М. Слабошпицького, «діяла некерована внутрішня сила, незалежна від його бажань чи настроїв» [Слабошпицький 2003: 195], що, зрештою, заводила “машину його таланту”. Трагічно-безвихідна атмосфера навколо нього («Увесь ландшафт для поета - ие горе, голод, смерть, страх, пожежі та байдужі до земного пекла небеса» [Слабошпицький 2003: 16]) та почасти прояви психічного захворювання стали чи не найвизначальнішими причинами “пекельності” його життя, в якому Тодось Осьмачка найперше виконував місію митця - творця художнього слова.

Як засвідчує роман М. Слабошпицького, формування художнього образу Тодося Осьмачки відбувалося у вкрай несприятливій політичній атмосфері, що зумовило підірвану психосистему персонажа: «Доба була наскрізь шизофренічна з типовим параноїком на чолі, з масами тупих півінтелігентів, які вірили йому (Сталіну. - А.Ч.), бо не знали нічого кращого» [Слабошпицький 2003: 229]. Не дивно, що за таких умов відбулося руйнування цілісності особистості, що спричинило психічні зрушення, нервові зриви, роздвоєність, невпевненість, страхи. Героєві вдалося уникнути обставин, які загрожували його творчій та духовній загибелі, натомість він ще більше заглибився у фізичний та психологічний стан самості, 
який поглибився 3 еміграцією. «Ось вона, омріяна самотність захист від переслідувачів і просто надто иікавих, що намагаються влізти в його рукописи, думки і дні» [Слабошпицький 2003: 218], зазначав автор. Осьмаччина одиночність призвела героя до важких психологічних потрясінь. Герой дедалі частіше занурювався у себе. М. Слабошпицький, аналізуючи душевний стан свого героя, відзначав, що «він уникав приязні, рімуче втікав від людей у свої підозри, тривоги, страхи, не хотів знати нічого доброго й не вірив у ніщуо добре. Надто самотній иче був чоловік і надто охоче та послідовно він плекав свою самотність» [Слабошпицький 2003: 276]. Ймовірно, Тодось Осьмачка однаково був приречений на самотність, бо в стані самості він перебував ще й до від’ізду за кордон. Навіть участь у літературному “МУРівському” відродженні не врятувала його від самотності, попри те, що активна культурницька діяльність головно сприяє адаптуванню особи до нового соціуму, культурного та політичного середовища: «Вагому підставу в цььому процесі становлення письменника в умовах еміграції відіграє його особиста роль у житті емігрантського середовища, оскільки тоді над ним тяжіють не лише певні стереотипи місия й часу, а й також певна «місія» в емігрантському житті й літературі» [Сиваченко 2010: 247-248], - зауважує Г. Сиваченко.

Утиски тоталітарного режиму відчував на собі й Рафаель Багаутдінов, хоча хронологічно йому випало пережити інший період радянської влади, ідеологія якої спрямована на винищення ментального коріння та духовного стрижня, позбавлення душевної розради та матеріальної опори, урівняння усіх класів і прошарків. «У тій чи іншій формі (страхом, приниженням непомічання, відчуттям ущербності, емочійною замороженістю як наслідком казарменного дитинства позародинним колом, різними комплексами й фобіями, щуо почалися в тих чорних роках) ми всі зазнали, кожен по-своєму, хай у різний час, переслідувань радянського режиму» [Слабошпицький 2008 a: 105], - висновує герой. Ця теза відправна точка в аналізі психологічного портрета Рафаеля Багаутдінова. Важкі умови життя у дитячій колонії та притулку вироби- 
ли у нього здатність відстоювати свою позицію, себе, свої думки, не покладаючись ні на кого. Звідси у Рафаеля Багаутдінова й показова риса характеру - безпретензійність, що з гідністю допомагала йому пройти життєві випробування: «Рідкісна це в нього риса: ніколи не мати ні до кого претензій, бути майже адвокатом кожному» [Слабошпицький 2008 а: 28]. Ця характеротворча якість сприяла вимуштруванню самостійності й автономності, а також безпосередності й незалежності, поінколи навіть формуючи потяг до волі-свободи як екзистенційної необхідності в умовах «заблокованої культури» (Л. Костенко).

Життєві ситуації, що випали на долю Рафаеля Багаутдінова, сприяли виробленню різних поведінкових моделей. Так, скажімо, спосіб життя у притулку й колонії виробив у героя та його брата специфічну поведінку, підпорядковану законам колоніального співжиття - крадіжки, бійки, обман: «Опинивиись в колонії, Рем $i$ Рафаель почали жити за ї̈ законами. За ними вже були й крадіж-

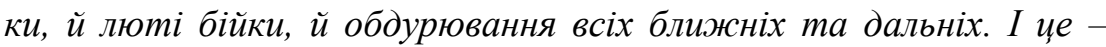
нормально в таких умовах, бо інакше вони не змогли б. Інакше їм не дозволили б» [Слабошпицький 2008 a: 35]. Така поведінка й спосіб існування сформували у братів особливе світовідчуття, грунтоване на психології ізгоїв та сиріт. Рафаелевому психостану сприяли не лише дитбудинківські умови життя, а й біль за скалічену долю батьків, за ущербленість у ментальних правах, за усвідомлення своєї непотрібності й настороженості світу до них.

Арешт батька й материне заслання - ще одна ключова подія у житті братів, що призвела до глибокої психологічної травми i безпосередньо вплинула на їхнє подальше життя. «Усе, щзо почалося з того дня, коли їх з Ремом після арешту батьків запроторили до так званого дитячого прийомника в Казані (маленьку Аїду забрала бабуся), й аж до того дня, коли нарешті попрощався $з$ колонією, - то його ходіння по муках» [Слабошпицький 2008 a: 167168], - пояснює М. Слабошпицький. Ця теза посутньо пояснює витоки Рафаелевої витривалості, стриманості, мінімалізму потреб, 
внутрішній муштрі та міцному самоконтролю як необхідних рис адаптування до нестерпних умов життя.

Батьківсько-материнський генокод героя як відлуння ментального осердя потужно формує й психічну ауру його життя: психологічне чуття невидимої присутності батька й розірваний зв'язок із матір'ю накладає своє відображення на свідомість Рафаеля Багаутдінова-людину. Як зауважує 3. Фройд, “один із зв’язків Я (читаймо свідомість. - А. Ч.) зі своїм неврозом такий очевидний, що його можна помітити з самого початку. Його, здається, не бракує ніде, але найвиразніше він проступає при тих ураженнях, до розуміння яких нам сьогодні ще далеко, - при травматичних неврозах (письмівка 3. Фройда. - А. Ч.)" [Фройд 1998: 385]. Материнське ув'язення й батьківський розстріл створили ситуацію психологічної травми, яка зрідка проявлялася у психоневрозі, зовнішньо малопроявленому, однак із важкими наслідками для душевного стану й психічного розвитку героя. За цією психотравмою у його свідомості криється система конфліктів - внутрішньоособистісних, сімейних, ідеологічних, політичних, що відобразилося й на світоглядній картині Рафаеля Багаутдінова. Видимим виразником такого травматичного психоневрозу стало формування відчуження й відокремлення від матері: «Рафаель майже не пам'ятав матері. I коли побачив ї̈ вперше після довгої розлуки аж 1949-го (йому на той час було вже вісімнадцять), то відчув, щзо між ними стоїть якийсь незримий бар'єр, якого вони обоє так $і$ не змогли подолати аж до ї̈ смерті» [Слабошпицький 2008 a: 23]. Внутрішнє відгородження, дистанціювання від материнської опіки й любові виробили у героя своєрідний комплекс недолюбленості, відчуття несправедливості й порожнечі. Травма втрати батька, якого герой прагнув знати і який йому постійно ввижався в мареннях і снах, перейшла у психічну потребу самореалізуватися й відбутися як людина і як митець, щоб виправдати батьківські очікування, оскільки саме батько дав Рафаелеві його ім'я, що також є вагомим психологічним ключем до розкодування його психологічного портрета. Ім'я Рафаеля - це ключ до його духовного, культурного й мента- 
льного осердя. «Якби я не був художником, може б, од імені свого й не знічувався б. Але иікаво: психологи кажуть, щзо ім'я значною мірою формує особистість» [Слабошпицький 2008 : 106], - зауважує Рафаель Багаутдінов, відчуваючи відповідальність за смислове й енергетичне наповнення свого ймення. Між іншим, відповідальність - ще одна засаднича риса характеротворення Рафаеля Багаутдінова поруч із скромністю й високою самодисципліною.

Як засвідчує роман М. Слабошпицького “Автопортрет художника в зрілості”, Рафаель Багаутдінов - людина високої моралі, згенерованої численними життєвими колізіями. Він - у міру амбіційний, активний, психічно зрілий за рахунок витривалості, терпеливості й гнучкості, що виробилися у нього впродовж навчання та на початкових етапах реалізації своїх здібностей.

У сильній психологічній залежності від творчості перебував і Никифор Дровняк, чию складну і важко зрозумілу психіку доцільно пояснювати у єдиному зчепленні з малюванням і жебрацтвом, а також складним захворюванням і фізичною неповноцінністю. Його дитинність зумовлена дебілізмом, а дитячість його психологічної організації - потягом до наївного мистецтва, заснованого на філософії пантеїзму. Дитячість Никифорового мислення підкреслено демонструє автентичність і самобутність його світоставлення, сформованого важким сирітським дитинством.

Художник представлений як самотня особистість із потужним інтуїтивним осердям. Він - відокремлений і самотинний щодо людей, але цілісний і гармонійний у єдності з природою. Його психічний вектор спрямований не на комунікаційні властивості 3 людьми, а на розчинення його свідомості, інтуїції і фантазії у світі природи. Звідси він виглядав дивно, насторожено, відлюдькувато. «Він був самотнім у своєму страшному дитинстві $і$ в усіх подальших роках. I в пору гучного успіху лишався таким же самотнім. I, гадається, не тільки тому, щуо від усіх інших людей його відділяли глухота й німота, бо кожен митець завжди самотній у своїй роботі» [Слабошпицький 1995: 111], - зауважує М. Слабошпицький. Никифорова самотність звернена на пізнання самого себе, а 
не на генерування власних сил і думок із метою сублімації їх у продукти мистецької фантазії.

У психоаналітичному вимірі засадниим елементом психообразу Никифора Дровняка є його інтуїтивно-фантастичний зв'язок iз матір'ю, образ якої цілісно проявлений у сповідях-монологах героя, наближений до потоку свідомості. Матір у романі - не лише художній образ, а й могутня сила і зворотній зв'язок Никифорового підсвідомого, а почасти й свідомого з його ментальним і духовним корінням. «... а материна рука мені на голові - як спокійна, тепла птаха; птаха охороняє мене від лиха й наруги, змушує вмовкати страх і тривоги душі, відвертає вітри й дощіџ [Слабошпицький 1995: 90], - зауважує Никифорові думки автор. За народними віруваннями, «Бог-Творець вселив у птахів душі дідів-прадідів та надприродні сили» [Жайворонок 2006: 489], відтак надумана материнська протекція, ймовірно, виражає несвідоме прагнення героя звернутися до своїх пращурів і до батька, якого ніколи не знав, але від якого отримав дар малювати. Мати в Никифоровій свідомості виконує функцію духовного опікуна й захисника, а також уособлює його несвідоме прагнення до домашнього огрітку, якого герой ніколи не мав, тобто до того уявного світу, що його здатна створити мати-птаха.

Щире духовне єднанням із матір'ю відчувається й у Михайла Коцюбинського. У романі М. Слабошпицького «Що записано в книгу життя» внутрішньодушевний психологічний портрет залежить від саморозкриття героя, який значно охочіше розповідав про своє дитинство, ніж про теперішнє. Свідома самонарація Михайла Коцюбинського у творі - не лише продумана наратологічна концепція, а й простір для проникнення у психосвіт героя, який той ретельно приховував від стороннього ока. Інформації про дитинство Михайла Коцюбинського небагато, однак і цього достатньо, щоб сформувати уявлення про Коцюбинського-дитину і спроектувати їі на майбутнє письменника. «Мені здається, щуо я весь - од матері. В неї- глибока душевна організація, вона завжди готова на самопожертву, особливо - для мене, бо ж безмежно мене лю- 
бить. [...] У нас подібні характери та вподобання. Я виростав цілкковито під ї̈ впливом» [Слабошпицький 2012: 26], - висновує герой, який наголошує на жертовності як одній із засадничих рис власного характеру. У майбутньому жертовність сформує у героя екзистенційні проблеми вибору, що призвело до психологічних інсайтів, важких роздумів над своєю долею.

Загалом, як засвідчує роман, Михайло Коцюбинський притримувався спокійного, розміренного життя. «Але життя Кочюбинського - життя без екстремізму» [Слабошпицький 2012: 54], - наголошує М. Слабошпицький, обмовляючись лише про любовний трикутник, що витворив для героя своєрідну екзистенційну й психологічну пастку. Михайло Коцюбинський був тактовним, смиренним, відповідальним, безкорисливим, уважним і стриманим, на чому акцентують його друзі. «Важко навіть уявити, щяоб Михайло Михайлович із когось покпинив, когось узяв на глузи - він лишався однаково до всіх прихильний та приязний» [Слабошпицький 2012: 71] (Володимир Самійленко). Набір подібних героєвих рис є наслідком глибокого самоконтролю й самодисципліни, що постійно тримала його у сильній психологічній залежності від думки оточуючих. Ймовірно, такий самоконтроль виробив у Михайла Коцюбинського й іншу - швидше негативну - рису його вдачі - потаємність, а часом і відчуження. У спілкуванні з людьми, колегами, іншими письменниками він помітно дистанціювався, чим створював враження людини непідступної і гордої: «Він не тільки тримає вас на відстані, він і сам тримається на відстані. Він на диво гордий, а тому й поводиться відповідно» [Слабошпицький 2012: 128]. Така поведінкова тактика Михайла Коцюбинського пояснюється 3 позицій поміркованості, розважливості й розсудливості. Сам герой себе вважав «людиною-межею» [Слабошпицький 2012: 233], відтак він ніколи не впадав у крайнощі, притримувався самоконтролю, що, зрештою, вберегло його психічну систему від видимих серйозних психічних зрушень, як, скажімо, Марії Башкирцевої чи Тодося Осьмачки. Однак за зовнішнім спокоєм Михайла Коцюбинського приховувався важкий психострес, 
викликаний хворобою, любовним зв'язком із Олександрою Аплаксіною, матеріальними незгодами, канцелярською службою. «Була у Коцюбинського і така непрохана гостя, як хронічна перевтома, були виснаження, неврози. I все ж ще більшим його ворогом було невдоволення нецікавою роботою» [Слабошпицький 2012: 212], зауважує М.Слабошпицький. Творчість духовно його вирівнювала й урівноважувала, однак повільно підточувала фізичні сили. Як зауважує Н. Зборовська, «творчість передусім знімає психічні збудження і накопичення невдоволених бажань автора» [Боровська 2003: 93], потверджуючи тезу, ніби творчість Михайла Коцюбинського виконувала компенсаторну функцію організму: брала на себе первинний і потужний удар психіки. Звідси й глибина, зраненість, болючість деяких тем художніх творів Коцюбинськогопротипу. Однак варто зауважити, що безперервна творча й канцелярська робота призвела Михайла Коцюбинського до тяжкої і невиліковної хвороби - центрового вузла його психічного переживання й екзистенційного вакууму.

М. Слабошпицький, орієнтуючись на духовні й характеротворчі вектори Михайла Коцюбинського, акцентує на одній із прикметних ознак, спільних для митців багатьох поколінь, - самотності, яка у його героя має ряд відмінних психічних ознак від самотності Марії Башкирцевої, Тодося Осьмачки, Никифора Дровняка. Почасти Михайло Коцюбинський прагнув усамітнення, що уявлялося йому своєрідним прихистком. Він прагнув іiі як необхідної потреби розібратися зі своїми проблемами. «Самотність. Самотність може стати мені щзонайпершими ліками. Те, чого не витримують $і$ від чого втікають інші, для мене може бути фортецеею душі» [Слабошпицький 2012: 31], - коментує герой. Таке прагнення усамітнення не суперечило його вдачі, швидше, навпаки, демонструє наслідковий характер його поведінки, способу життя, світогляду. Самотність Михайла Коцюбинського - каталізатор емоційно стриманого і поміркованого настрою героя, вона його дисциплінувала й дистанціювала від родини і колег, почасти перетворючись у тривожність, депресивне згнічення, замкнутість, втому. 
Отже, у романі “Марія Башкирцева (Життя за гороскопом)", "Поет із пекла (Тодось Осьмачка)”, “Никифор Дровняк із Криниці”, “Автопортрет художника в зрілості” та “Що записано в книгу життя” М. Слабошпицький проявив себе як майстер напруженої психологічної драми, в якій сконденсовані гострі проблеми часу, цікаві людські долі, вималювані художньо довершені типажі головних героїв тощо. Український письменник достеменно передав фізичний і психічний стани своїх героїв, змалював складні образи українських художників і письменників, висвітливши ключові психологічні засади формування їхніх переконань, особливостей психічної вдачі, елементи світоставлення, систему характеротворчих якостей і рис, а також їхню непросту душевну організацію.

\section{БІБЛІОГРАФІЯ}

Жайворонок 2006 - Жайворонок В. Знаки української етнокультури: Словникдовідник / В. Жайворонок. - К. : Довіра, 2006. - 703 с.

Зборовська 2003 - Зборовська Н. Психоаналіз і літературознавство: посібник /Н. Зборовська. - К. : Академвидав, 2003. - 392 с.

Сиваченко 2010 - Сиваченко Г. Візія Франції в емігрантських творах Володимира Винниченка / Г. Сиваченко // Наукові записки. - Випуск 92. - Серія: Філолгічні науки (літературознавство, мовознавство). - Кіровоград : РВВ КДПУ ім. В. Винниченка, 2010. $-476 \mathrm{c}$.

Слабошпицький 2008 a - Слабошпицький М. Автопортрет художника в зрілості / М. Слабошпицький. - К. : Ярославів Вал, 2008. - 288 с.

Слабошпицький 2008 б - Слабошпицький М. Марія Башкирцева (Життя за гороскопом) / М. Слабошпицький. - К. : Ярославів Вал, 2008. - 272 с.

Слабошпицький 2003 - Слабошпицький М. Поет із пекла (Тодось Осьмачка) / М. Слабошпицький. - К. : Ярославів Вал, 2003. - 367 с.

Слабошпицький 1995 - Слабошпицький М. Тодось Осьмачка. Никифор Дровняк із Криниці: Роман-колаж (фрагменти) / М. Слабошпицький. - К.: Рада, 1995. - 142 с. Слабошпицький 2012 - Слабошпицький М. Що записано в книгу життя: Михайло Коцюбинський та інші: роман / М. Слабошпицький. - К. : Ярославів Вал, 2012. -352 c.

Фройд 1998 - Фройд 3. Вступ до психоаналізу / З. Фройд ; пер. 3 нім. П. Таращук. К. : Основи, 1998. - 709 с.

Стаття надійшла 12 вересня 2013 p. 